\title{
Lithostratigraphic contact - a significant site for hydrogeological investigation in crystalline fractured-rock terrains
}

\author{
TAPas Acharya ${ }^{1, *}$ and Rajesh Prasad ${ }^{1,2}$ \\ ${ }^{1}$ Department of Geology, Hooghly Mohsin College (University of Burdwan), Chinsurah 712 101, India. \\ ${ }^{2}$ Present address: Geological Survey of India, SU, Gujarat, India. \\ *Corresponding author. e-mail: tacharya3@yahoo.com
}

Estimating the hydrogeologic control of fractured aquifers in hard crystalline and metamorphosed rocks is challenging due to complexity in the development of secondary porosity. The present study in the Precambrian metamorphic terrain in and around the Balarampur of Purulia district, West Bengal, India, aims to estimate the hydrogeologic significance of lithostratigraphic contacts using fracture characteristics obtained from surface bedrock exposures supported by hydrological data from the existing dugwells. This study involves the domain-wise analysis of the frequencies of fractures that control the fractureporosity. The domain-wise study reveals higher fracture-frequencies adjacent to the lithostratigraphic contacts. The concurrence of lithostratigraphic contacts with the occurrences of high-discharging wells and also with the deep weathered zone in low-lying areas is clearly established, thus assigning the lithostratigraphic contact as hydrogeologically significant. An increase in frequencies of the fractures within the 'influence zone' of the lithocontact, is clearly visible. Among those fractures, particularly, which make the angle greater than the 'limiting angle' with the lithocontact are characterised by increased frequencies. However, brittle rocks like quartz biotite granite gneisses, phyllite and epidiorite show high porosity of fracture, within the 'influence zone' of the lithostratigraphic contact. Enhanced deepening of the weathered-zone at lower topographic region may perhaps be a plausible explanation for this increased fracture-porosity at lithocontact to assign it as a hydrogeologically significant transmissive zone within fractured rocks.

\section{Introduction}

Groundwater is a valuable resource in the present day but of limited extent, particularly in igneous and metamorphic rocks. Exploration of groundwater potential zones is a major problem in metamorphic crystalline terrain. No permanent solution has been found so far. Three reasons have contributed to water supply problems in metamorphic crystalline rocks: (i) secondary porosity of the rocks, (ii) underlying heterogeneous characteristics and (iii) problem of identification of suitable fractures.
Practical experiences of many hydrogeologists were that suggestion of locations for dug wells, tube wells and drill wells in crystalline metamorphic and igneous terrain did not always yield a good success rate, demanding more investigations of the locales of hydraulically significant fractures in Precambrian metamorphic rocks. Groundwater movement in igneous and metamorphic rocks is controlled largely by rock type (lithology), discontinuities due to compositional differences and fractures (joints and/or faults), topography, depth of weathering, nature and size of the recharge area

Keywords. Fractured rocks; lithostratigraphic contact; fracture frequency; hydrogeology; metamorphic rocks. 
and discharge area, and the spatial relationships of these factors (Neretnieks 1985; Crawford and Brackett 1995). Crawford and Brackett (1995) also concluded that the above-mentioned features/ factors provide secondary permeability, which allows infiltration of precipitation and movement of water subsurface. It is suggested that physical properties such as seismic velocity, dielectric constant and electrical resistivity on either side of the lithological contacts differ significantly. Ladeira and Price (1980) documented different fracture spacings at the lithological contacts. It is assumed that fractures with higher frequency may represent more potentially transmissive bedrocks (Mabee and Hardcastle 1997). Several workers (Braathen 1999; Henriksen and Braathen 2006; Boutt et al. 2010; Acharya et al. 2012) have pointed out enhanced permeability associated with the hydraulically significant and flowing fracture-sets with high frequencies. The main objective of this work is to study the hydrogeologic importance of lithostratigraphic contact and evaluate its influence on the frequencies of fractures, which are responsible for developing higher fracture porosity in hard crystalline and metamorphosed rocks.

\section{Study area}

Geologically, the study area is located at the junction of Chhotanagpur Granite Gneissic Complex (CGGC) and the Singhbhum Group (SG) of rocks of Proterozoic age (Geological Quadrangle Map 73I 1948; Baidya 1992; Gupta and Basu 2000) in Purulia district, West Bengal, India (figure 1). On the north, CGGC is a part of the Chhotanagpur craton consisting different types of granite gneisses, such as quartz-biotite granite gneiss. This is dominated by quartz and porphyroblastic granite gneiss rich in garnet porphyroblasts, which is responsible for the brittle nature of this rock group. The SG exposed on the south belongs to the Singhbhum orogenic belt and comprises chiefly of mica schist and phyllite. These rocks are rich in micaceous minerals imparting a ductile nature in them. The metasediments of SG are inter-layered with basic bodies, locally described as epidiorite sills (Geological Quadrangle Map 73I 1948), composed mainly of hornblende. NW-SE foliations are well developed both in the CGGC and the metasedimentaries of SG (Geological Quadrangle Map 73I 1948). The rocks have no primary porosity and water flows are restricted to fracture zones. The dip of foliations is high and northerly directed. A general E-W strike with northerly dip $\left(>57^{\circ}\right)$ of the foliation is the dominant fabric of the metamorphites of the CGC (Sengupta and Sarkar 1964; Ghose 1983; Mazumder 1988; Sarkar 1988; Baidya 1992). The monotonous northerly dip may be ascribed to isoclinal folds with overturned southern limb in the present area. The compositional banding in gneisses is parallel to the regional foliation. The monotonous roughly $\mathrm{E}-\mathrm{W}$ strike of the metamorphites suggests that the folds are non-plunging or gently plunging towards $\mathrm{E}$ or $\mathrm{W}$. The presence of more than one generation minor foldings is observed that bears the imprinting of polyphase deformation. The geometry of the first generation folding is not visible owing to the absence of competent exposures. Precambrian rocks of the area have undergone three phases of folding (Baidya 1992). The first two deformations, F1 and F2, had produced $\mathrm{E}-\mathrm{W}$ axial planes. F1 is not well preserved. F2 is the dominant and well preserved deformational event, which had produced tight, isoclinal, $\mathrm{E}-\mathrm{W}$ trending axial planar foliation (S2) in all rock types. F3 has N-S axial plane and is open in nature.

A prominent shear zone trends almost $\mathrm{E}-\mathrm{W}$ through the south of Balarampur town and is named as the 'South Purulia Shear Zone' (SPSZ) and it possesses features of a brittle-ductile deformational regime (Bhattacharya 1989; Dasgupta 2004) (marked in figure 1). There is evidence that shear forces acted along some $\mathrm{E}-\mathrm{W}$ trending nearvertical weak planes, during the third tectonic period (Geological quadrangle map 73I 1948). The SPSZ, delimiting the northern margin of SG, 150 $\mathrm{km}$ long and $4-6 \mathrm{~km}$ wide, is roughly an E-W trending lineament. A thrust has brought CGGC to the south over SG (Katti et al. 2010). The structural elements are dominantly shear-joints and fractures in the granitic rocks, pegmatites, quartz veins and metasediments. These shear fractures, joints and faults, in general, strike $\mathrm{E}-\mathrm{W}$ with $60^{\circ} \mathrm{N}$ to near-vertical dips (Geological quadrangle map 73I 1948). The rocks are medium to coarse-grained with augens of feldspar or quartz with mylonitic matrix, with the asymmetric shear sense indicators suggesting sinistral movement.

\section{Hydrogeological set-up}

In the water table contour maps of pre-monsoon (figure 2) and post-monsoon (figure 3 ) seasons of 2012 , the variation in groundwater contour spacing indicates a strong variation of hydraulic gradient in the study area. The depth to groundwater could broadly be categorised into five groups, namely, <3, 3-5, 5-7, 7-9 and 9-10 $\mathrm{m}$ bgl. The depth-to-water table during the pre-monsoon season ranges from 2 to $10 \mathrm{~m} \mathrm{bgl}$, while the same fluctuates between 1.7 and $9.89 \mathrm{~m} \mathrm{bgl}$ during the post-monsoon months. The pre-monsoon depth-towater table contourmap (figure 2) reveals shallow (within $5 \mathrm{~m} \mathrm{bgl}$ ) water table conditions in the 


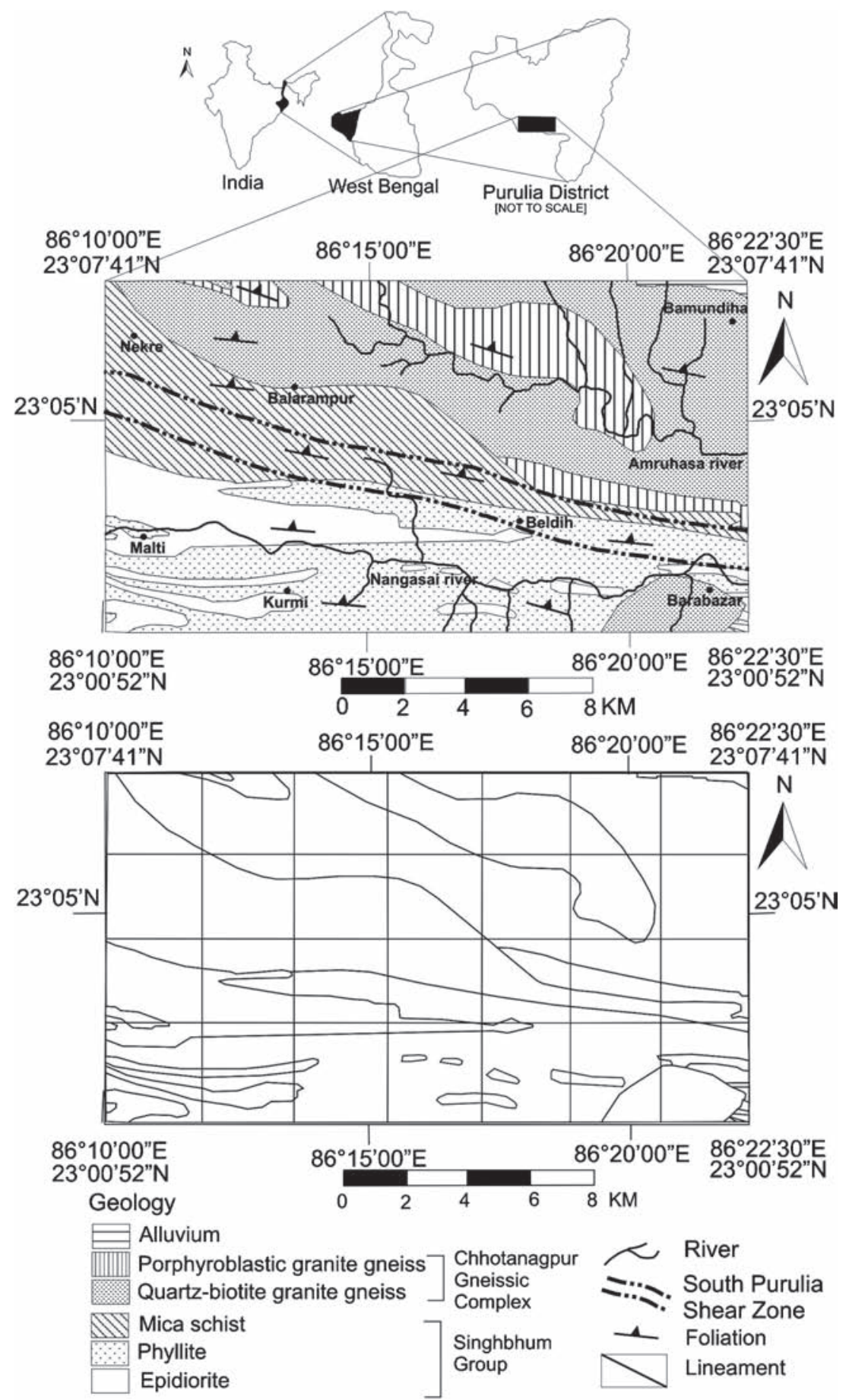

Figure 1. Location map of the study area in and around Balarampur, Purulia district, West Bengal, India, showing geological features and grids.

central and southern parts of the study area. The depth-to-water table contour map during the postmonsoon period (figure 3) exhibits the shallowest position at the southern part with some similar stray pockets at the northern and central portions. Study of divergence pattern of flow lines at the southern and central parts of the study area during pre- and post-monsoon periods indicate recharge possibilities at these areas. A comparative review of the pre- and post-monsoon contour data has also indicated storativity status of the aquifers, as a direct response to recharge-discharge characteristics. A good correlation could be established between well-jointed and permeable rock strata. For example, high rise in water table noted in the post-monsoon season on the southern part of the study area and moderately high water table values of north-central region could be attributed to 


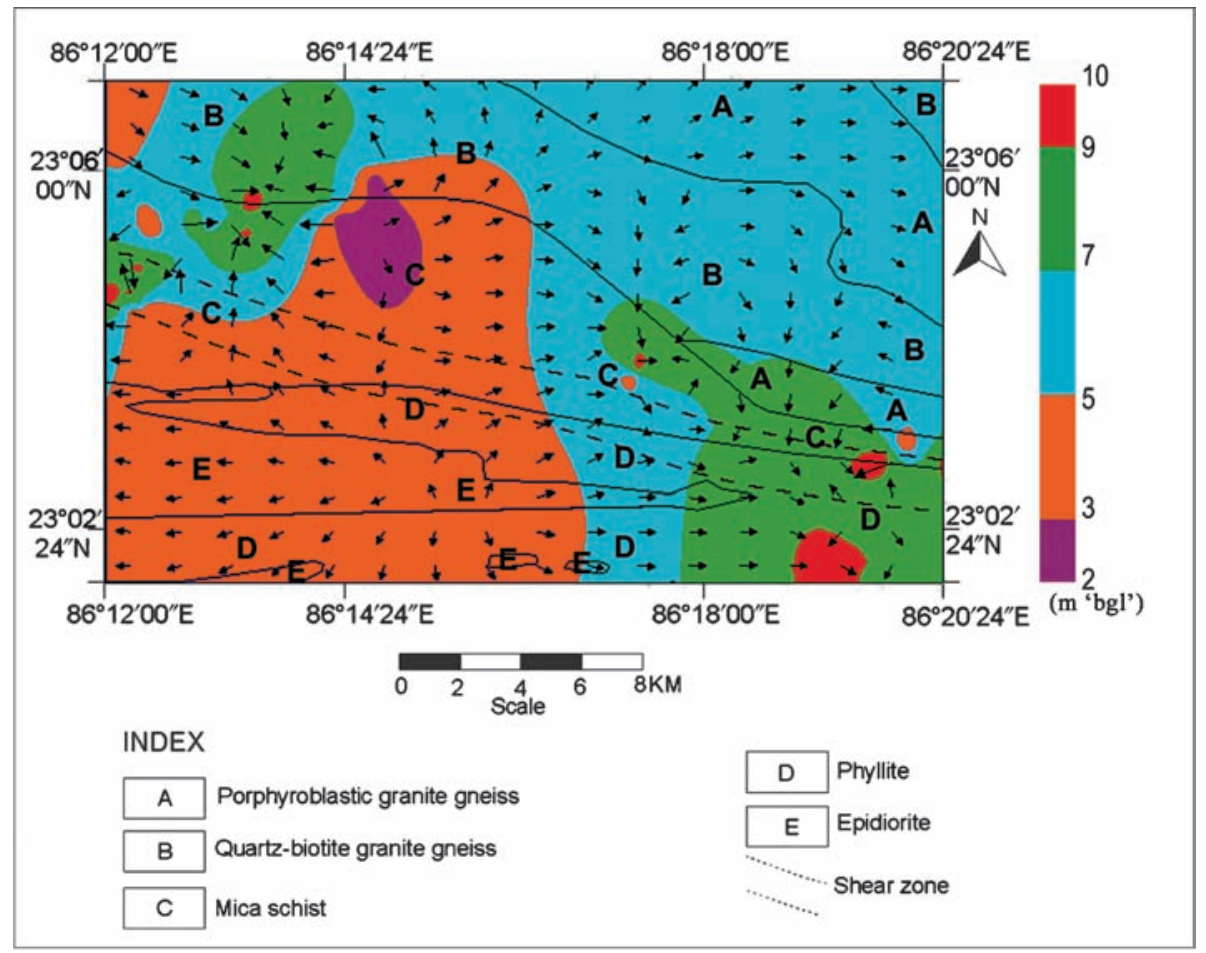

Figure 2. Water level contour map, in ' $\mathrm{m}$ bgl' and groundwater flow lines of the study area at pre-monsoon time in session 2012 showing hydraulically permeable locales and recharge areas near lithostratigraphic contacts.

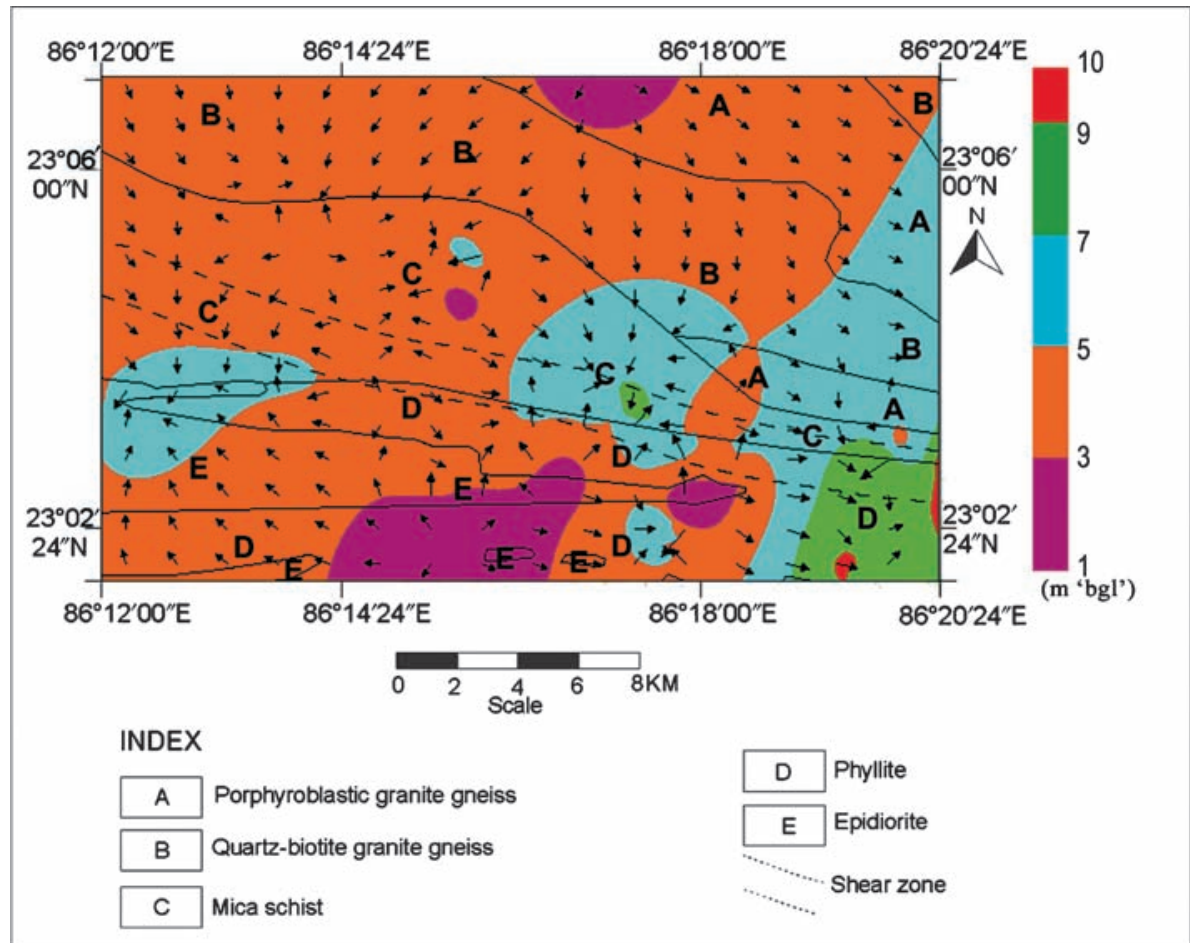

Figure 3. Water level contour map, in ' $\mathrm{m}$ bgl' and groundwater flow lines of the study area at post-monsoon time in session 2012 showing hydraulically permeable locales and recharge areas near lithostratigraphic contacts.

the existence of permeable joint systems. Higher permeability was noted in small pockets in the proximity to lithological boundaries of phyllites, epidiorite and quartz-biotite granite gneiss.

\section{Methods}

The methods used in this study are hydrostructural domain analysis of Mackie (2002) and sub-domain 
grid-wise analysis for the characterisation of fracture-frequency and fracture-porosity. The techniques mainly include: (1) fracture analysis, (2) dugwell data analysis, (3) study of depth of weathered zone, and (4) topographic analysis. The study area is divided into 28 grid cells with at least 3 exposures of fractures within each grid. Each grid or domain has a dimension of $3 \times 3 \mathrm{~km}$ area. Domains have been numbered as $\mathrm{g}_{11}, \mathrm{~g}_{12}$, $\mathrm{g}_{13}$, etc., where ' $\mathrm{g}$ ' corresponds to the grid, the first numerical in the subscript indicates the row, and the second number in the subscript indicates the corresponding column. Thus, for example, $\mathrm{g}_{13}$ belongs to the first row and third column (figure 1). Fracture/joint characteristics from outcrops and groundwater discharges of the existing dugwells of larger diameter have been obtained from field studies. Water discharge of dugwells are obtained from the information of the daily usage of water by the villagers and hence measured on daily basis and the unit is also kept as litre per day (lpd). Water usage calculation is a semiquantitative method. This discharge is dependent upon the degree of exploitation of the dugwells and hence the discharges obtained are exploitation discharge, which is mainly used as potable water and small area irrigation. This area is one of the arid and drought-prone regions in West Bengal, where scarcity of groundwater is a chronic problem. This exploitation discharge is not equivalent to the yield of the dugwell. By comparing the usage of the dugwells an attempt has been made to fix the dugwells with higher exploitation discharge. It is assumed, in this hydrogeological condition, that wells of higher usages and higher exploitation discharges are the representatives of high-discharging dugwells. Thus no relationship among the location of wells, or groups of wells and the water needs exists in this area. Hence, the higher discharge is only linked to the hydrodynamic properties of the fractured rocks. 48 high-discharging ( $\geq 4000 \mathrm{lpd})$ dugwells (Acharya and Prasad 2014) are selected to investigate the spatial correlation between the location of high-discharging dugwells and lithostratigraphic contacts. Analysis of depth of weathered zone and topography in the regions are carried out to find out the correlation among location of high-discharging wells, lithostratographic contact, deep weathered zone and lower topography.

\subsection{Fracture study}

Fractures (or joints) are planes along which stress has caused partial loss of cohesion in the rock (Cook 2003). Fracture orientation and frequency have been used to characterise fractures observed at the outcrops. Fracture orientation is obtained by measuring strike and dip of the fractures at the outcrop. Fracture frequency is measured by the number of fractures occurring in one metre perpendicular to the trend of parallel/co-parallel fractures. High fracture-frequency means closely spaced fractures. It is assumed that fractures that are more closely spaced enhance porosity and may represent bedrock that is potentially more transmissive (Mabee and Hardcastle 1997; Acharya and Basumallik 2012). Acharya et al. (2012) suggested that fractures with fracture frequency $>15 / \mathrm{m}$ are hydraulically significant. Hydraulically significant fractures are flowing fractures characterised by an increase in permeability, which appear to result from an increase in the density of fracturing, i.e., fracture frequency giving rise to a higher connectivity of the fracture networks (Boutt et al. 2010). Enhanced permeability is associated with the fracture set showing high fracture-frequency (Braathen 1999; Henriksen and Braathen 2006). The closer the fractures are placed, the more is the tendency of groundwater to flow along those closely spaced fractures (Acharya and Basumallik 2012), causing potential weathering along the flow path, facilitating to produce potential aquifer (Acharya and Prasad 2014).

\subsubsection{Analyses of fracture-frequency}

Facture-frequency data were classified into two groups: (i) grids consisting of a single lithology and (ii) grids containing at least one lithostratigraphic contact. Fracture-frequencies are used to produce histograms for each lithology: (1) for grids of single lithology and (2) for grids having lithostratigraphic contact with the neighbouring lithological unit. This analysis is performed particularly for gneissic rock and mica schist (figure 4). Such analysis is not done for porphyroblastic granite gneiss, epidiorite and phyllite because of the absence of grids with single porphyroblastic granite gneiss, epidiorite and phyllite litho-units. The quartz-biotite granite gneiss exhibits higher modal value of fracture frequencies $(5 / \mathrm{m})$ in the domains where it has a contact with porphyroblastic granite gneiss (figure 4c) and with mica schist (figure $4 \mathrm{~d}$ ) than the modal value $(2 / \mathrm{m})$ represented in the domains of quartz-biotite granite gneiss without any lithostratigraphic contact (figure 4a). Higher modal fracture-frequencies are clearly visible for mica schist within the domains having lithostratigraphic contacts with gneisses $(10 / \mathrm{m})$ (figure $4 \mathrm{e})$ and with phyllite $(15 / \mathrm{m})$ (figure 4f) than the modal fracture-frequency in mica schist of the grids without any lithostratigraphic contact $(5 / \mathrm{m})$ (figure $4 \mathrm{~b})$. The histograms clearly indicate higher fracture-frequency in the 


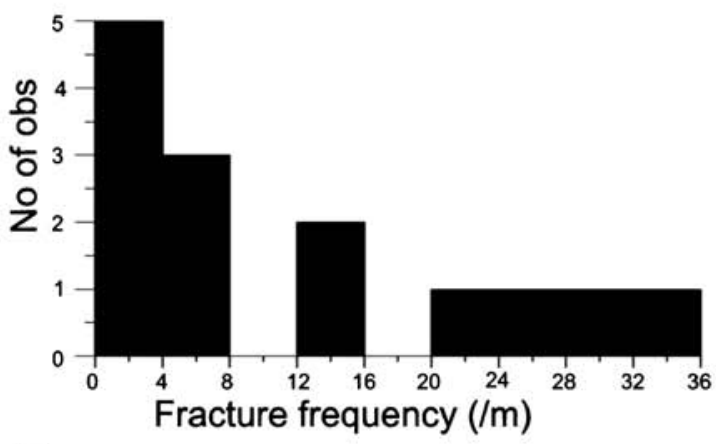

(a)

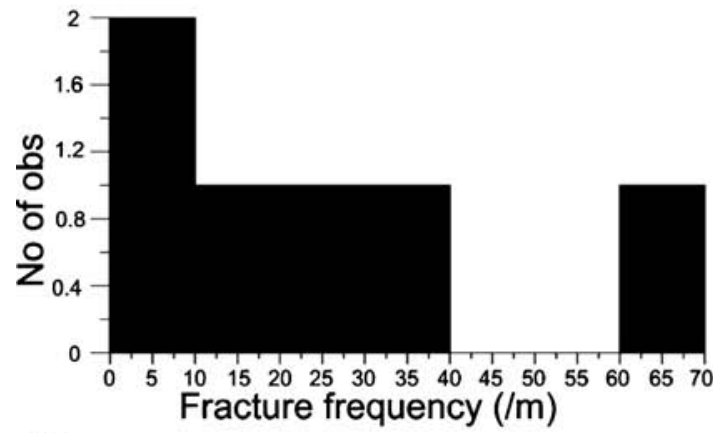

(b)
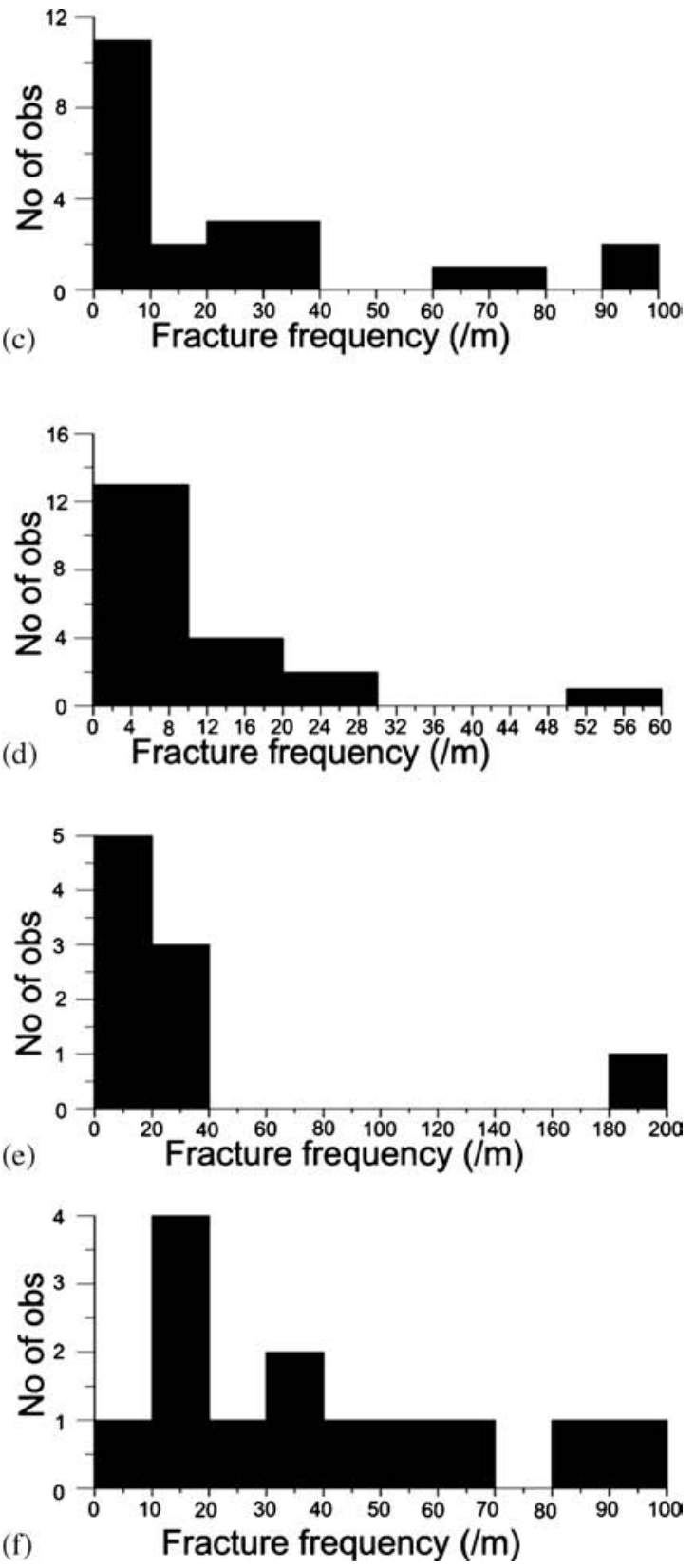

Figure 4. Modal values of fracture-frequencies for (a) quartz biotite granite gneiss, (b) mica schist for domains having no lithological contact; quartz biotite granite gneiss having contact (c) with porphyroblastic granite gneiss and (d) with mica schist; mica schist having contact (e) with gneissic rock and (f) with phyllite.

Table 1. Variation in fracture frequency for grids without lithostratigraphic contact and for grids having lithological contacts (FF: Fracture Frequency).

\begin{tabular}{lcc}
\hline Rock type & $\begin{array}{c}\text { FF without contact } \\
\text { (modal value) }\end{array}$ & $\begin{array}{c}\text { FF with contact } \\
\text { (modal value })\end{array}$ \\
\hline Quartz-biotite granite gneiss & 2 & $\left\{\begin{array}{l}5 \text { In contact with porphyroblastic granite gneiss } \\
5 \text { In contact with mica schist }\end{array}\right.$ \\
Mica schist & 5 & $\left\{\begin{array}{l}10 \text { In contact with quartz biotite granite gneiss } \\
15 \text { In contact with phyllite }\end{array}\right.$ \\
\hline
\end{tabular}

domains with lithocontacts. The histograms of frequencies of fractures (figure 4) show that the grids with lithostratigraphic contacts are characterised by higher modal values of fracture-frequency than single lithologic domain without any lithostratigraphic contact (table 1), assigning zones of lithological contacts having higher fracture-porosity than areas with a single lithostratigraphic unit. 
Spatial anisotropy in fracture-frequency values from the lithological contact have been analysed (figure 5) to study the influence of lithostratigraphic contact on fracture-frequency. Fracturefrequencies are plotted with their corresponding distance measured perpendicularly from the nearest lithostratigraphic contact spatially in quartzbiotite granite gneiss, phyllite and epidiorite (figure $5 \mathrm{a}, \mathrm{b}$ and $\mathrm{c}$, respectively). The analysis shows that fracture-frequency is high at the proximity of lithostratigraphic contacts and decreases with distance from contacts particularly for quartz biotite granite gneiss having contact with porphyroblastic granite gneiss; phyllite having contact with epidiorite; and epidiorite having contact with phyllite (figure 5a, b and c, respectively). A sharp increase in frequencies of fractures is observed within a particular distance from the lithostratigraphic contacts, attributing increased fracture-frequency near the contact. Also, this limiting distance from the lithocontact for high frequencies of fractures may be assigned as the 'influence zone' of the lithostratigraphic contact. The influence zone for gneissic rock is found to be about $900 \mathrm{~m}$ from the contact (figure 5a) and that for phyllite having contact with epidiorite is about $320 \mathrm{~m}$ from contact (figure 5b) and also for epidiorite having contact with phyllite is $80 \mathrm{~m}$ from the contact (figure 5c). This influence zone implies that beyond this distance from the contact, the fracture frequency decreases abruptly. Such a phenomenon is not observed for mica schist having contact with phyllite, epidiorite and gneissic rocks and also for gneissic rock having contact with mica schist.

Fracture-frequencies are examined and categorised into two groups: (i) within influence zone and (ii) outside influence zone. Fracture-frequencies of each set (i.e., within and outside influence zone) are analysed for fractures with varying strikes making varying angle to the local lithostratigraphic contact. The angle between each fracture of single lithology and the same contact is determined. This angle of each fracture is studied with their corresponding frequencies and analysed graphically (figure 5d, e and $\mathrm{f}$ ). The solid curves represent the fracture data with influence zone of the contacts and the dashed curves are for the fracture dataset outside the influence zone of the corresponding contacts. The curves show variation in fracture-frequency within and outside

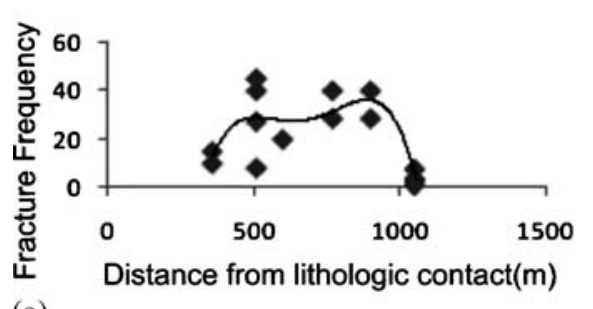

(a)

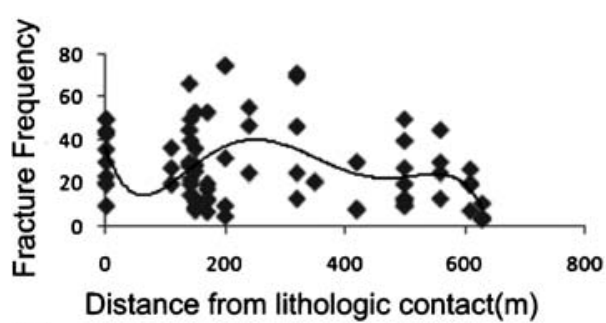

(b)

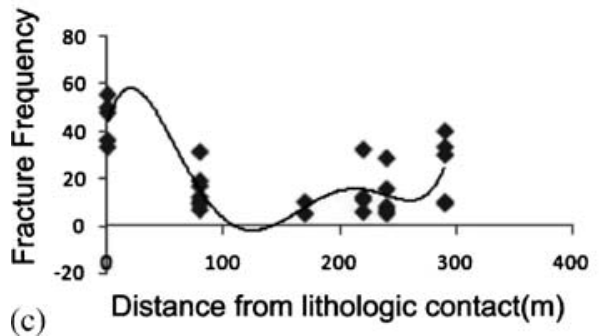

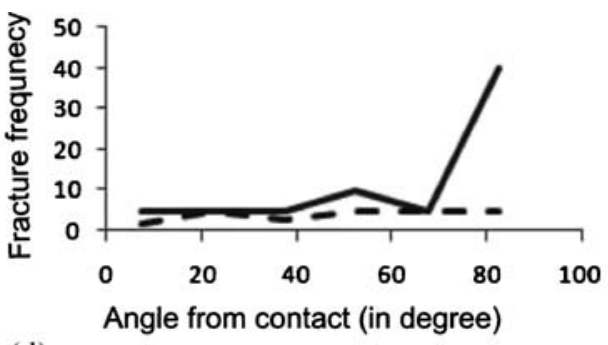

(d)

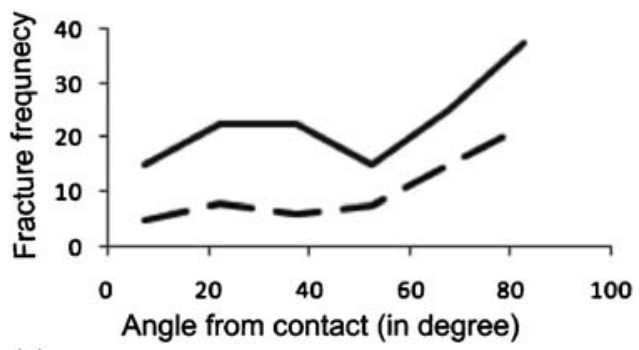

(e)

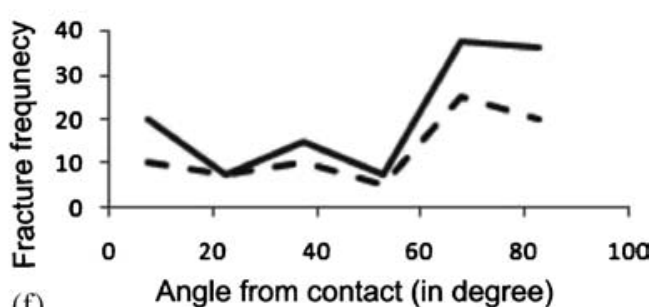

(f) Angle from contact (in degree)

Figure 5. Variation in frequencies of fractures with its distance from lithocontact in single lithological domain: (a) quartz biotite granite gneiss, (b) phyllite and (c) epidiorite. Variation of frequencies of fractures making different angle with lithocontact in single lithological domain: (d) quartz biotite granite gneiss, (e) phyllite and (f) epidiorite within influence zone (solid curve) and outside influence zone (dashed curve) of lithocontact. 
the influence zone of lithostratigraphic contacts (figure 5d, e and f). Fracture-frequencies are clearly higher in the influence zones of the contacts. The fractures within the influence zone of the corresponding lithostratigraphic contacts show abruptly high fracture-frequencies for the fractures making a high angle to the contacts. The angle above which the fractures show abruptly high frequencies may be termed as the 'limiting angle' and this varies with different lithology. This limiting angle is higher in quartz-biotite granite gneiss, i.e., $\geq 70^{\circ}$ (figure $5 \mathrm{~d}$ ) than that of in phyllite, i.e., $\geq 50^{\circ}$ (figure $5 \mathrm{e}$ ) and epidiorite, i.e., $\geq 50^{\circ}$ (figure $5 \mathrm{f}$ ).

\subsubsection{Analyses of fracture trend}

Rose diagram of fractures (i) within the influence zone and (ii) outside the influence zone, in quartz-

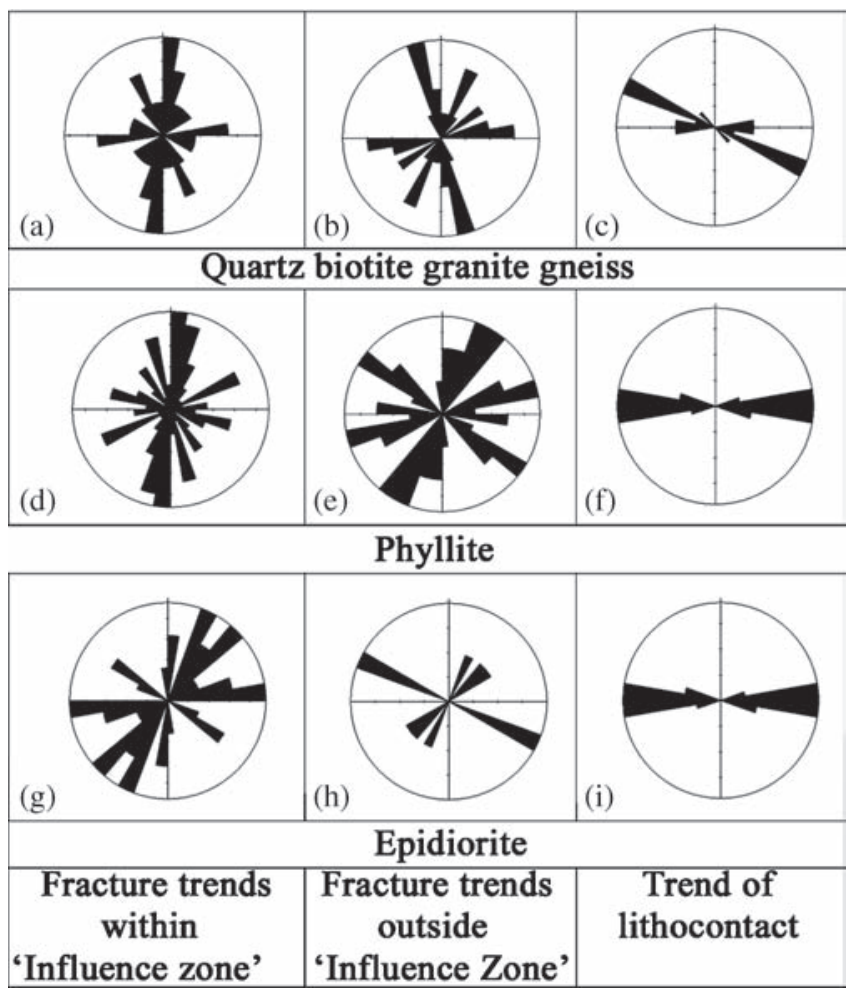

Figure 6. Azimuth frequency (Rose) diagrams of fracture orientations within and outside 'Influence Zone' and trends of lithocontacts in quartz biotite granite gneiss $(\mathbf{a}, \mathbf{b}, \mathbf{c})$, phyllite $(\mathbf{d}, \mathbf{e}, \mathbf{f})$ and epidiorite $(\mathbf{g}, \mathbf{h}, \mathbf{i})$, respectively. biotite granite gneiss, phyllite and epidiorite have been prepared for a comparative analysis of dominant fracture trends in each lithology. Within influence zone, quartz-biotite granite gneiss shows dominant fractures trend along the $\mathrm{N}-\mathrm{S}$ direction (figure 6a), while dominant fractures are trending along the $\mathrm{N}-\mathrm{S}$ direction in phyllite (figure $6 \mathrm{~b}$ ) and $\mathrm{NE}-\mathrm{SW}$ and $\mathrm{E}-\mathrm{W}$ directions in epidiorite (figure $6 \mathrm{c}$ ). Outside influence zone, dominant fracture trends are along the $\mathrm{N}-\mathrm{S}$ direction in quartz-biotite granite gneiss (figure 6d), NE-SW, E-W and SE-NW directions in phyllite (figure 6e) and SE-NW direction in epidiorite (figure 6f). The dominant trend of lithocontact for each lithology is plotted in rose diagrams, indicating a $\mathrm{SE}-\mathrm{NW}$ trending dominant lithocontact in quartz-biotite granite gneiss (figure $6 \mathrm{~g}$ ). The dominant lithocontact in both phyllite and epidiorite are trending along the $\mathrm{E}-\mathrm{W}$ direction (figure $6 \mathrm{~h}, \mathrm{i}$ ). The outcome of the analysis of rose diagrams is tabulated in table 2 . Analysis of the dominant trends in rose diagrams and table 2 reveals that major fractures in quartz biotite granite gneiss are at a high angle to the lithostratigraphic contact both within and outside the influence zone. The dominant fractures in phyllite trend at a high angle to the lithostratigraphic contact within the influence zone. One of the dominant fracture-trends in epidiorite within the influence zone makes a high angle to lithostratigraphic contact. These rose diagrams of fracture trends show that fractures in phyllite and epidiorite are at a higher angle to the contacts, followed by the fractures in quartz biotite granite gneiss within the influence zone, which are perhaps responsible for the development of the higher fracture-frequency in phyllite and epidiorite near lithocontact.

\subsection{Spatial analysis of high-discharging dugwells}

A total of 48 existing high-discharging wells $(\geq 4000$ lpd) in the study area were recorded (figure 7 ) and their spatial distribution were analysed critically. The spatial analysis reveals clustering of the dugwells in groups (figure 7), indicating a systematic distribution of high-discharging dugwells. These occur in 10 distinct groups in the study area. Each

Table 2. Lithology-wise variation in dominant fracture-trends within and outside the influence zone of lithocontacts and dominant trends of the lithocontacts in each lithology.

\begin{tabular}{lccc}
\hline Rock type & $\begin{array}{c}\text { Dominant fracture trend } \\
\text { within influence zone of } \\
\text { lithocontact }\end{array}$ & $\begin{array}{c}\text { Dominant fracture trend } \\
\text { outside influence zone of } \\
\text { lithocontact }\end{array}$ & $\begin{array}{c}\text { Dominant trend of } \\
\text { lithocontact }\end{array}$ \\
\hline $\begin{array}{l}\text { Quartz-biotite granite gneiss } \\
\text { Phyllite }\end{array}$ & $\mathrm{N}-\mathrm{S}$ & $\mathrm{N}-\mathrm{S}$ & $\mathrm{SE}-\mathrm{NW}$ \\
Epidiorite & $\mathrm{N}-\mathrm{S}$ & $\mathrm{NE}-\mathrm{SW}, \mathrm{E}-\mathrm{W}$ and SE-NW & $\mathrm{E}-\mathrm{W}$ \\
$\mathrm{NE}-\mathrm{SW}$ and E-W & SE-NW & E-W \\
\hline
\end{tabular}




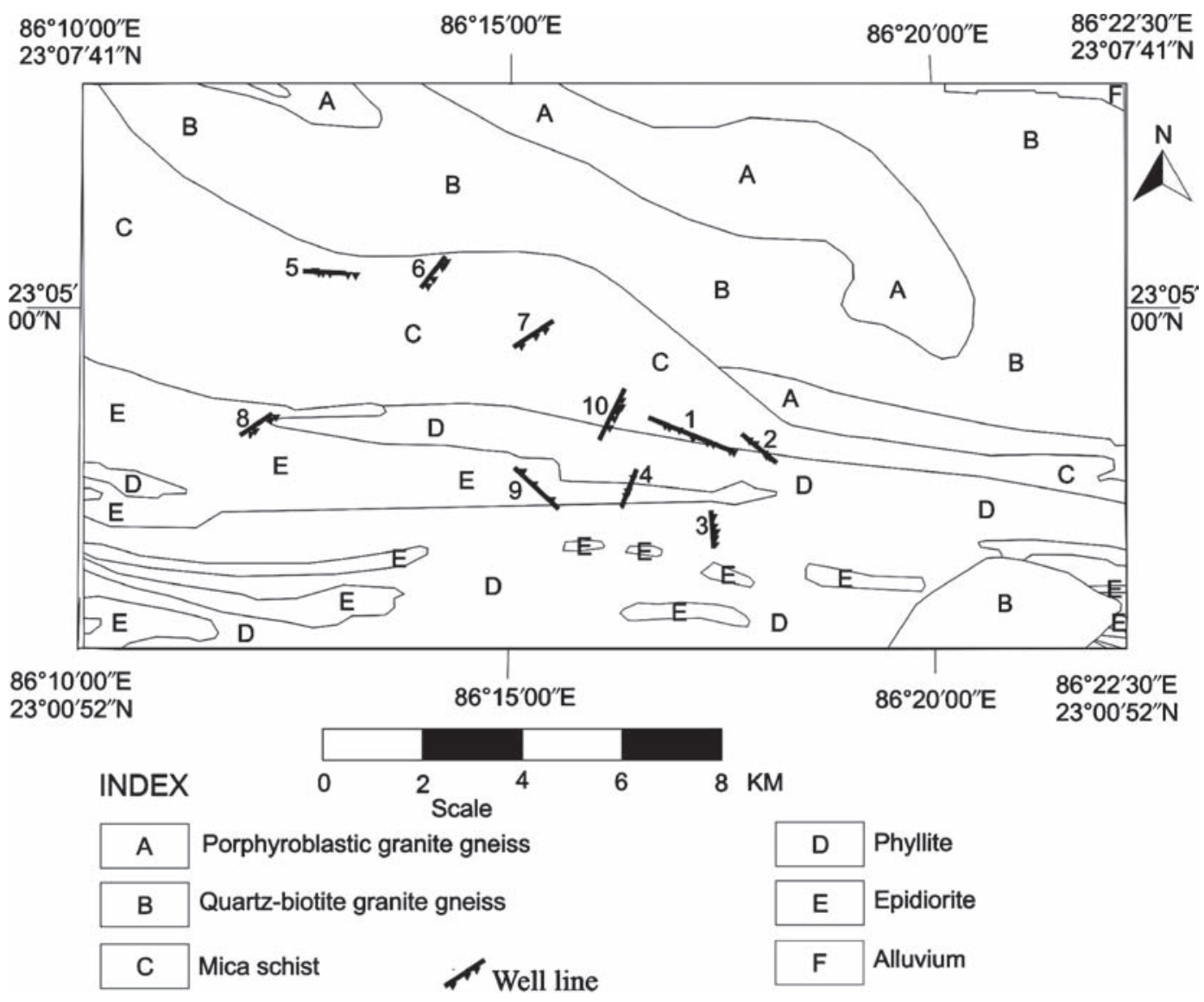

Figure 7. Map showing the spatial distribution of high-discharging wells in well-lines close proximity to lithological contacts.

group of high-discharging dugwells exhibits a spatial distribution of dugwells in straight lines. Thus, the 10 groups of high-discharging dugwells assign 10 definite spatial linear trends of dugwell locations (table 3) and henceforth, these lines are designated as 'dugwell-line', numbered from 1 to 10 in figure 7. Thus, dugwell-lines, showing locations of high-discharging dugwells, may perhaps indicate a hydraulically significant geological feature. These dugwell-lines follow the valley region near the cultivated area. The villagers by their experiences with digging dugwells in the area also discovered that the high-discharging dugwells are located along a straight line and thereafter they continued selecting the dugwell sites along these straight lines. The representative mode value and $C v$ of dugwell-discharges from each dugwell-line have been calculated using Statistica (StatSoft Inc. 1995) software and tabulated in table 3. Statistical analysis shows representative mode dugwelldischarges on each dugwell-line ranging from 4000 to $11950 \mathrm{lpd}$ along with low $C v$ ranging from 0.02 to 0.35 , indicating nearly isotropic high discharges of dugwells sited on the same dugwell-line. Abruptly high dugwell discharges with very low $C v$ is also clearly exhibited for dugwell-line number 4 (mode discharge $11950 \mathrm{lpd}$; $C v$ 0.02) and dugwell-line number 10 (mode discharge 118000 lpd; Cv 0.09) (table 3). Interestingly, the majority of the dugwell-lines, except dugwell-line number 7 , are spatially very close to the lithological contacts (figure 7). Spatial analysis of the high-discharging wells $(\geq 4000 \mathrm{lpd})$ reveals their preferential occurrences proximal to the lithostratigraphic contacts in quartz biotite granite gneiss, phyllite and epidiorite. This close association of high-discharging wells with the lithostratigraphic contact is also supported by Lachassagne et al. (2011) and Dewandel et al. (2011).

\subsection{Weathered zone thickness analysis}

Dugwells are extended below the ground level within the saprolite and weathered zone. The depths of the dugwlls are, hence, considered as the depth of weathered zone at those locations and are taken into account to construct the contour map of the depth of weathered zone in the study area. The thickness of weathered zone is obtained from the data of depth to dugwell-base below ground level (bgl). The contour map (figure 8) of depth of the weathered zone displays the spatial variation of the thickness of weathered zone in the study area. Analysis of contour map (figure 8) of weathered zone thickness shows the occurrence of a thick weathered zone in the central, southern and southeastern portions of the study area. These deep 
Table 3. Spatial trends of well-lines with well discharges over each well-line, modal representative and Coefficient of variance $(C v)$ of well discharges for each well-line; lpd: liter per day, WDWL: well discharges over 'well-line'.

\begin{tabular}{|c|c|c|c|c|c|c|}
\hline 'Well-line' no. & $\begin{array}{l}\text { Trend of } \\
\text { 'well-line' }\end{array}$ & $\begin{array}{l}\text { WDWL } \\
\text { (lpd) }\end{array}$ & $\begin{array}{l}\text { Depth to the well } \\
\text { base }(\mathrm{m} \mathrm{bgl})\end{array}$ & $\begin{array}{l}\text { Depth to water } \\
\text { (m bgl })\end{array}$ & $\begin{array}{l}\text { Modal WDWL } \\
\text { (lpd) }\end{array}$ & $C v$ of WDWL \\
\hline 1 & $112^{\circ}-292^{\circ}$ & $\begin{array}{l}4100 \\
4500 \\
5500 \\
6500 \\
4000 \\
5000 \\
6000 \\
4100\end{array}$ & $\begin{array}{l}11 \\
11.4 \\
11 \\
12.4 \\
10.8 \\
10.5 \\
12.1 \\
11.7\end{array}$ & $\begin{array}{l}6.9 \\
4.9 \\
7.75 \\
6.95 \\
7.01 \\
6.83 \\
4.65 \\
6.3\end{array}$ & 4100 & 0.19 \\
\hline 2 & $145^{\circ}-325^{\circ}$ & $\begin{array}{l}4200 \\
6500 \\
4000 \\
6000\end{array}$ & $\begin{array}{l}10.8 \\
11 \\
8.8 \\
10.3\end{array}$ & $\begin{array}{l}5.6 \\
5.2 \\
4.42 \\
8.05\end{array}$ & 4000 & 0.24 \\
\hline 3 & $0^{\circ}-180^{\circ}$ & $\begin{array}{l}4000 \\
6800 \\
4400 \\
4000 \\
5600 \\
5900\end{array}$ & $\begin{array}{l}10.7 \\
14.3 \\
10 \\
10.4 \\
11.5 \\
12\end{array}$ & $\begin{array}{l}7 \\
5.4 \\
6 \\
4.05 \\
6.45 \\
5.65\end{array}$ & 5500 & 0.22 \\
\hline 4 & $20^{\circ}-200^{\circ}$ & $\begin{array}{l}11500 \\
12000 \\
12000\end{array}$ & $\begin{array}{l}12.6 \\
12 \\
12.2\end{array}$ & $\begin{array}{l}2.25 \\
2.1 \\
2.45\end{array}$ & 11950 & 0.02 \\
\hline 5 & $95^{\circ}-275^{\circ}$ & $\begin{array}{l}9000 \\
4000 \\
4200 \\
5000 \\
4100 \\
6000\end{array}$ & $\begin{array}{l}11.8 \\
10.2 \\
10.8 \\
10.2 \\
9.4 \\
10\end{array}$ & $\left.\begin{array}{l}8.35 \\
8.05 \\
3.25 \\
8.1 \\
7.1 \\
6.4\end{array}\right\}$ & 4300 & 0.35 \\
\hline 6 & $40^{\circ}-220^{\circ}$ & $\begin{array}{l}8800 \\
8000 \\
6700 \\
9000 \\
6300\end{array}$ & $\begin{array}{l}11 \\
9.5 \\
9.8 \\
9.7 \\
8\end{array}$ & $\begin{array}{l}3.55 \\
4.45 \\
2.65 \\
3.2 \\
4.78\end{array}$ & 8800 & 0.15 \\
\hline 7 & $62^{\circ}-242^{\circ}$ & $\begin{array}{l}4400 \\
5000 \\
4000\end{array}$ & $\begin{array}{l}7.7 \\
10.8 \\
9.3\end{array}$ & $\begin{array}{l}3.05 \\
2.65 \\
4.6\end{array}$ & 4300 & 0.11 \\
\hline 8 & $65^{\circ}-245^{\circ}$ & $\begin{array}{l}4300 \\
4100 \\
4000 \\
4600\end{array}$ & $\begin{array}{l}9.7 \\
8.2 \\
8.7 \\
9\end{array}$ & $\begin{array}{l}1.4 \\
1.98 \\
1.1 \\
1.6\end{array}$ & 4100 & 0.06 \\
\hline 9 & $135^{\circ}-315^{\circ}$ & $\begin{array}{l}4000 \\
4200 \\
5000\end{array}$ & $\begin{array}{l}8.5 \\
10.6 \\
10.7\end{array}$ & $\begin{array}{l}4.1 \\
3.65 \\
2.35\end{array}$ & 4250 & 0.12 \\
\hline 10 & $23^{\circ}-203^{\circ}$ & $\begin{array}{r}9700 \\
11700 \\
9800 \\
12000 \\
12000 \\
11800\end{array}$ & $\begin{array}{l}14.3 \\
12 \\
10 \\
12.2 \\
11.2 \\
10.7\end{array}$ & $\begin{array}{l}5.5 \\
5.55 \\
4.85 \\
5.15 \\
5.05 \\
6.4\end{array}$ & 11800 & 0.09 \\
\hline
\end{tabular}




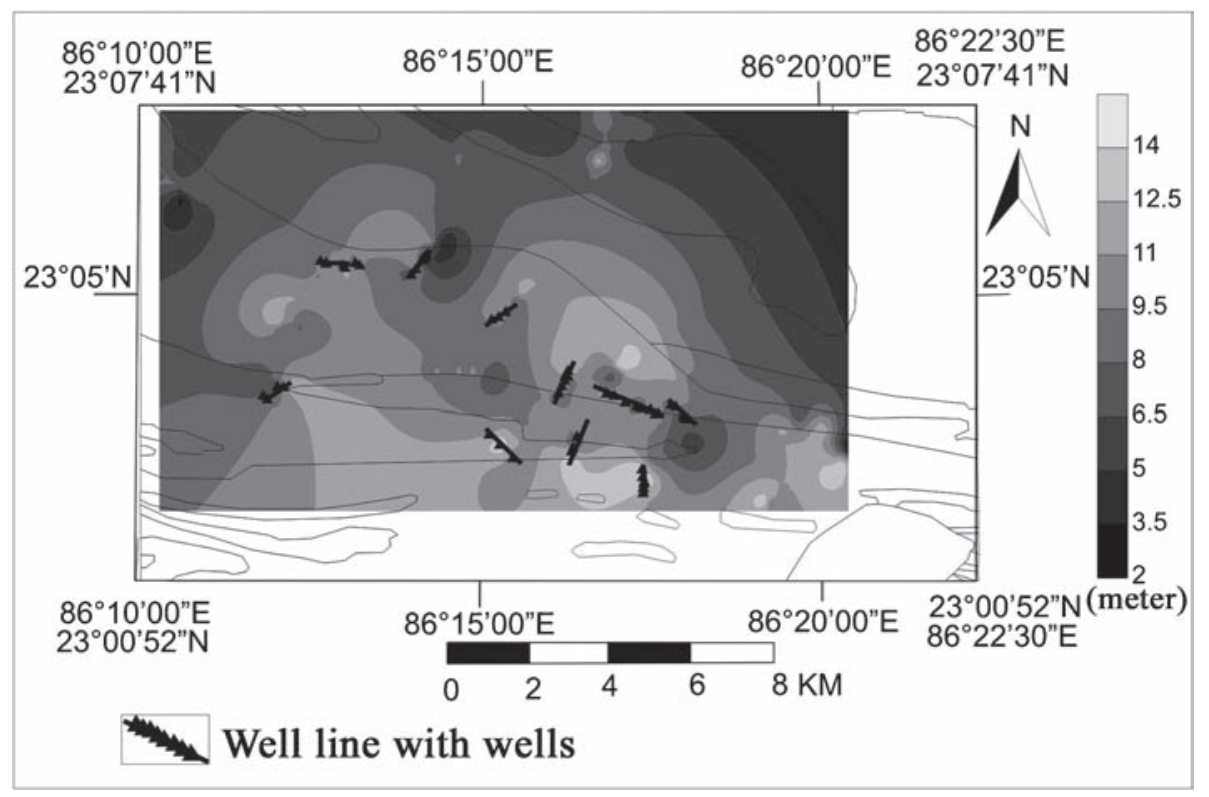

Figure 8. Contour map of thickness of weathered zone in the study area in meter, showing regions of deep saprolite and weathering concurrence with spatial occurrences of high-discharging dugwells.

weathered zones are concurrent to the locations' high-water-discharging dugwell-lines and are also close to lithostratigraphic contacts, indicating deep weathering at lithocontacts. The scatter-plot of dugwell discharge $v s$. depth of saprolite (figure 9) clearly indicates the positive correlation between the two.

\subsection{Effect of topography}

Topographic contour map of the study area has been prepared by digitising the contours of the toposheets and using ArcView GIS3.2 (ESRI 19921999) software (figure 10). An overlay of dugwelllines on the topographic contour map indicates clearly that high-discharging dugwell-lines are associated with low-lying regions, in which high rate of weathering most likely exists.

\section{Result and discussion}

Domain-wise analysis shows that fracture frequency of a single rock type is higher in the domains having lithological contacts than that in domains without any lithocontact, indicating domains with lithological contacts are hydrologically more important than domains with single lithology. Histogram of fracture frequency in same lithology for grids with (i) lithological contacts and (ii) single lithology shows that grids with lithological contacts are characterised by comparatively higher values of fracture-frequency than monolithic grids, indicating spatial correlation between high fracture-frequency with lithostratigraphic contact, which is also supported by several workers (Everitt et al. 1996).
Fracture-frequencies for a single lithostratigraphic unit shows a higher value near the lithostratigraphic contact, which decreases markedly after a particular distance from the lithostratigraphic contacts, particularly in granite gneisses and also in phyllite-epidiorite contact. This result is also supported by Deyell and Sherlock (2003) who suggested that deformation in the Elice Hills area, Committee Bay belt, Nunavut has resulted in dilational settings at lithological contact. Such a phenomenon is absent in the lithostratigraphic contacts involving mica schist. This is due to the ductile nature of the mica schist (Morland 1997; Banks and Robins 2002; Cook 2003). The limiting distance from the contact maintaining the higher fracture-frequency value is assigned as the 'influence zone' for the contact concerned, e.g., for granite gneissic rock $900 \mathrm{~m}$, phylliteepidiorite $320 \mathrm{~m}$ and epidiorite-phyllite $80 \mathrm{~m}$. The results clearly reveal the significant role of the lithostratigraphic; contact to influence and increase the fracture-frequency within its 'influence zone', assigning those fractures to be more hydrologically significant (Braathen 1999; Acharya et al. 2012) near the lithostratigraphic contact, in turn, assigning lithostratigraphic contact to be more hydraulically significant (Everitt et al. 1996). Furthermore, fractures, those are making higher angle than the 'limiting angle' with the lithostratigraphic contact concerned, i.e., $\geq 70^{\circ}$ in quartz-biotite granite gneiss and $\geq 50^{\circ}$ phyllite and epidiorite, clearly show a sharp and consistent increase in fracture-frequency within the influence zone' of the lithocontact. Very significantly dominant azimuthal rose of fractures within the 'influence zone' consistently show the angle higher than 


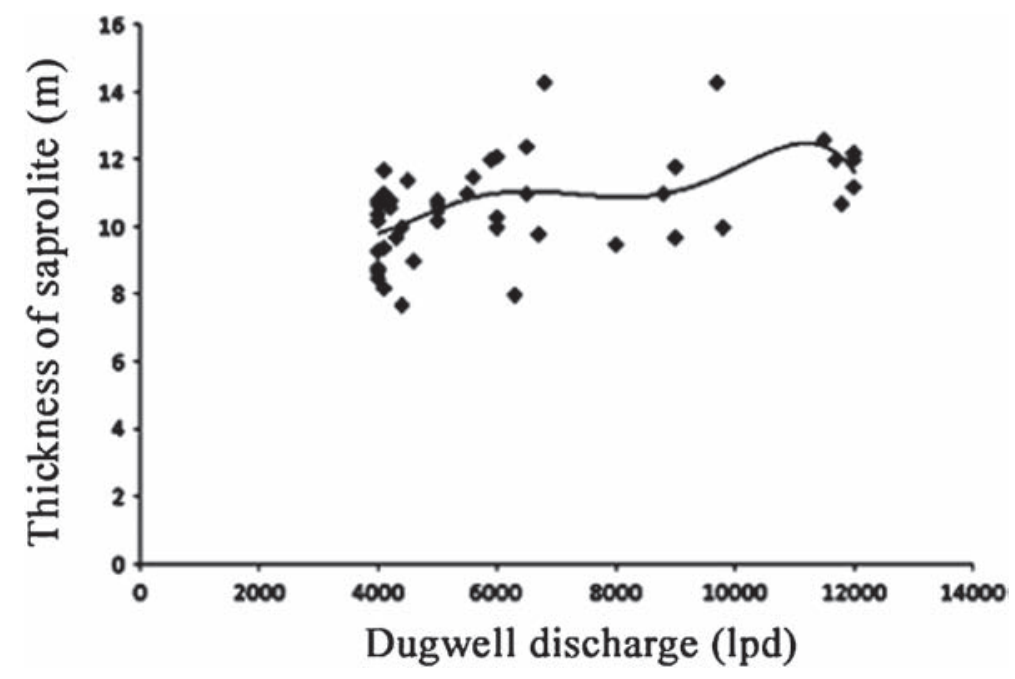

Figure 9. Scatter-plot of dugwell discharge vs. thickness of saprolite and weathered zone, showing increased discharge with thicker saprolite and weathered horizon.

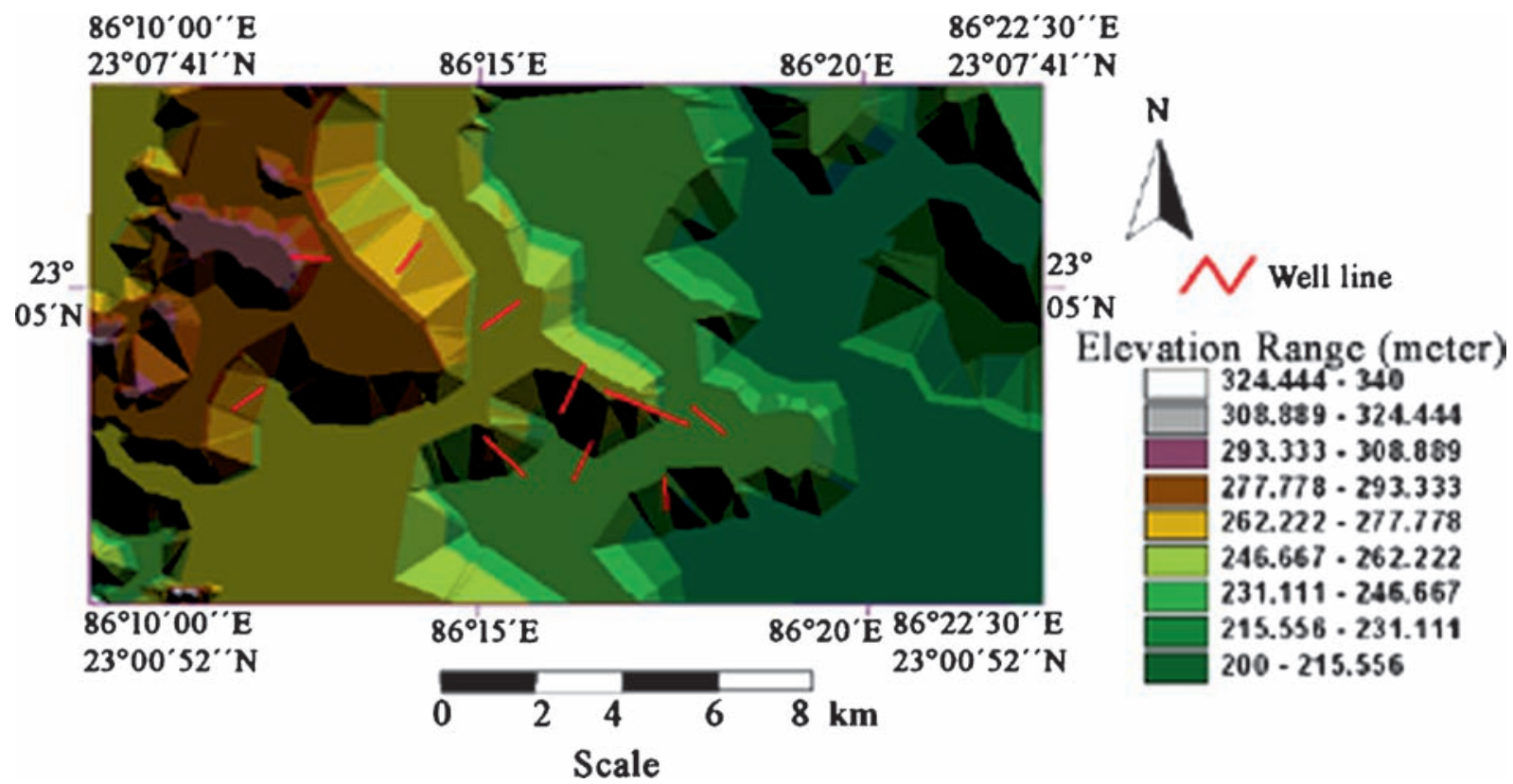

Figure 10. Topographic elevation map overlaid with the dugwell lines in the study area, showing occurrences of highdischarging wells in low-lying region.

that of 'limiting angle' for that lithology at these hydraulically significant lithocontacts. These zones are highly spatially consistent with the location of high-discharging well-lines. Deep weathering at the lithostratigraphic contact significantly coincides with high-discharging dugwells. Dugwell discharges significantly increase with the increase in thickness of the weathered zone. The highdischarging dugwells preferentially occupy lower elevations where there is the likelihood for a higher rate of weathering than erosion, thus significantly increasing the thickness of the weathered zone. This is also supported by several workers (LeGrand 1988; Mondal and Singh 2004; Dewandel et al. 2006, 2010, 2011; White and Burbey 2007; Lachassagne et al. 2011), who stated that the weathered layer formed by rock-weathering provides an intergranular medium, an important source in fractured aquifers. Dugwells with high discharge are spatially distributed in groups and occur in a linear fashion, designated as 'dugwellline', in each group. Orsi (2004) also observed that groups of high-discharging dugwells did, in fact, appear in lines, as found in this study. However, he suggested further hydrological and structural studies provide more conclusive results regarding the significance of linear distributions of high-discharging dugwells in a group. The present 
study demonstrates that the line, containing high-discharging dugwells in each group assigned as 'dugwell-line', actually occurs over a highly weathered zone with thick saprolite and fissured rock zones concurrent with lithostratigraphic contact and a subsurface intense fracture zone with deeper weathered zone (Acharya and Prasad 2014). Several studies (Neretnieks 1985; Crawford and Brackett 1995; Everitt et al. 1996; Deyell and Sherlock 2003; Lachassagne et al. 2011) demonstrated that along and near such lithologic contacts, differential deformation stress and weathering at low topographic region may often create zones of enhanced permeability and pathways for groundwater flow.

\section{Conclusion}

The study has demonstrated the importance of lithostratigraphic contact to evaluate its hydrogeological potential in a typical Precambrian metamorphic terrain involving the integration of spatial distribution of bedrock fracture, analysis of fracture properties, dugwell data, the study of the depth of weathered zone, and topography. This study, which evaluates the hydrogeological significance of lithostratigraphic contacts of crystalline fractured rock terrain in Balarampur (Purulia district, West Bengal, India), concludes the following. A grid-wise study is essential to demonstrate that lithocontacts are the regions of high fracturefrequency. These fractures, with high frequencies, are (a) within the 'influence zone' of lithocontact and (b) making a higher angle than the 'limiting angle' with the lithocontact. The hydrogeologically productive lithostratigraphic contacts make a higher angle than the 'limiting angle', i.e., $\geq 70^{\circ}$ in quartz biotite granite gneiss and $\geq 50^{\circ}$ in phyllite and epidiorite, with the dominant fracture-strikes occurring within the 'influence zone' of the contact. The study indicates the affinity of the occurrences of high-discharging dugwells close to the lithostratigraphic contacts. The lithostratigraphic contacts act as a significant zone of groundwater resources. A thick subsurface zone of weathering at the lithocontact in the low-lying area represents hydrogeologically significant transmissive zone within fractured rocks. The presence of lithostratigraphic contact enhances deepening of the weathered-zone in fractured Precambrian metamorphic rocks.

\section{Acknowledgements}

The authors are grateful to Prof. S K Nag and Prof. S Basumallik (retired) of Jadavpur
University, Kolkata, India, for their valuable advice, used in parts of this study. Authors are thankful to the corresponding editor, Dr. M Jayananda and two anonymous referees for their suggestions that improved the quality of the manuscript.

\section{References}

Acharya T and Prasad R 2014 Hydrodynamic study of the weathered zone of hardrock aquifers from dugwell data; Nat. Resour. Res. 23(3) 331-340.

Acharya T and Basumallik S 2012 Analysis of lineament swarms in a Precambrian metamorphic rocks in India; J. Earth Syst. Sci. 121(2) 453-462.

Acharya T, Nag S K and Basumallik S 2012 Hydraulic significance of fracture correlated lineaments in Precambrian rocks in Purulia District, West Bengal; J. Geol. Soc. India 80(5) 723-730.

Baidya T K 1992 Apatite-magnetite deposit in the Chhotanagpur Gneissic Complex, Panrkidih area, Purulia District, West Bengal; Indian J. Geol. 64(1) 88-95.

Banks D and Robins N 2002 An introduction to groundwater in crystalline bedrock; Geological Survey of Norway, Trondheim.

Bhattacharya D S 1989 Ductile shear zone in Purulia, WB, India; J. Geol. 61 172-178.

Boutt D F, Diggins P and Mabee S 2010 A field study (Massachusetts, USA) of the factors controlling the depth of groundwater flow systems in crystalline fractured-rock terrain; Hydrogeol. J. 18 1839-1854.

Braathen A 1999 Kinematics of post-Caledonian polyphase brittle faulting in the Sunnfjord region, western Norway; Tectonophys. 302 99-121.

Cook P G 2003 A guide to regional groundwater flow in fractured rock aquifers; CSIRO Land and Water, Australia.

Crawford T J and Brackett D A 1995 Ground water in igneous and metamorphic rocks; low-angle lithological contacts related to site-specific control of ground water occurrence; Proceedings Georgia Water Resources Conference, University of Georgia, Athens, Georgia.

Dasgupta S 2004 Modelling ancient orogens - An example from North Singhbhum Mobile Belt; GSI Spec. Publ. 84 $33-42$.

Dewandel B, Lachassagne P, Wyns R, Maréchal J C and Krishnamurthy N S 2006 A generalized 3-D geological and hydrogeological conceptual model of granite aquifers controlled by single or multiphase weathering; J. Hydrol. $330260-284$.

Dewandel B, Lachassagne P, Zaidi F K and Chandra S 2011 A conceptual hydrodynamic model of a geological discontinuity in hard rock aquifers: Example of a quartz reef in granitic terrain in south India; J. Hydrol. 405 474-487.

Dewandel B, Perrin J, Ahmed Sh, Aulong S, Hrkal Z, Lachassagne P, Samad M and Massuel S 2010 Development of a tool for managing groundwater resources in semi-arid hard rock regions. Application to a rural watershed in south India; Hydrol. Process. 24 2784-2797.

Deyell C and Sherlock R L 2003 Iron-formation-hosted gold occurrence in the Elice Hills area, Committee Bay belt, Nunavut, Geological Survey of Canada; Curr. Res. 200-C16.

Everitt R, McMurry J, Brown A and Davison C 1996 Geology of the Lac du Bonnet batholith, inside and out: $A E C L$ 's Underground Research Laboratory, Southeastern Manitoba (Field B5) 27209.

Geological Quadrangle Map 73I 1948 GSI, Calcutta. 
Ghose N C 1983 Geology, tectonics and evolution of the Chhotanagpur granite gneiss complex, eastern India; Recent Res. Geol. 10 211-247.

Gupta A and Basu A 2000 North Singhbhum Proterozoic mobile belt eastern India - A review; GSI Spec. Publ. 55 $195-226$.

Henriksen H and Braathen A 2006 Effects of fracturelineaments and in situ rock stresses on groundwater flow in hard rocks: A case study from Sunnfjord, Western Norway; Hydrogeol. J 14 444-461.

Katti V J, Sen J and Bhatt A K 2010 Uranium potentiality of South Purulia Shear Zone in Eastern Indian Shield; Technical Meeting on Low Grade Uranium Ore, 29-31 March 2010, International Atomic Energy Agency (IAEA), Vienna, Austria.

Lachassagne P, Wyns R and Dewandel B 2011 The fracture permeability of hard rock aquifers is due neither to tectonics, nor to unloading, but to weathering processes; Terra Nova. 23 145-161.

Ladeira F L and Price N J 1980 Relationship between fracture spacing and bed thickness; J. Struct. Geol. 3 179-184.

LeGrand H E 1988 Piedmont and Blue Ridge, Region 21 (chapter 24), In: The geology of North America (eds) Back W B, Rosenshein J S and Seaber P R, Vol. O-2: Hydrogeology, Boulder, Colorado: The Geological Society of America, Inc.

Mabee S B and Hardcastle K C 1997 Analyzing outcropscale fracture features to supplement investigations of bedrock aquifers; J. Struct. Geol. 5 21-36.

Mackie D M 2002 An integrated structural and hydrogeologic investigation of the fracture system in the Upper Cretaceous Nanaimo Group, southern Gulf Islands,
British Columbia [M.Sc. thesis]: Burnaby, Simon Fraser University, 358p.

Mazumder S K 1988 Crustal evolution of Chhotanagpur gneissic complex and the mica belt of Bihar; In: Precambrian of the Eastern Indian Shield (ed.) Mukhopadhyay D; Geol. Soc. India Memoir 8 49-83.

Mondal N C and Singh V S 2004 A new approach to delineate the groundwater recharge zone in hard rock terrain; Curr. Sci. 85(5) 658-662.

Morland G 1997 Petrology, lithology, bedrock structures, glaciation and sea level; Important factors for groundwater yield and composition of Norwegian bedrock boreholes? Norges Geol. Unders. Rapport 97122.

Neretnieks I 1985 Transport in fractured rocks; In: Proceeding of hydrogeology of rocks of low permeability; Memoir Int. Assoc. Hydrogeol. 17(2) 301-318.

Orsi C M 2004 Structural topographic, and Hydrogeological Analysis of the Montpelier Quadrangle: Central Vermont; Submitted in partial fulfillment of the requirements for the degree of Bachelor of Arts, Department of Geology, Middlebury College, Middlebury, Vermont.

Sarkar A N 1988 Tectonic evolution of the Chhotanagpur plateau and Gondwana basins in Eastern India: An interpretation based on supra-subduction geological processes; In: Precambrian of the Eastern Indian Shield (ed.) Mukhopadhyay D; Geol. Soc. India Memoir 8 127-146.

Sengupta D K and Sarkar S N 1964 Structure of the granitic rock and associated metamorphites of the area around Muri-Silli-Jhalida, Ranchi and Purulia districts, India; 22nd Int. Geol. Cong. 4 374-389.

White B A and Burbey T J 2007 Evidence for structurally controlled recharge in the Blue Ridge Province, Virginia, USA; Hydrogeol. J. 15(5) 929-943. 